\section{IN VIVO ACTIVATION BY POLYMYXIN B OF PHOSPHOLIPASE C FROM PSEUDOMONAS AERUGINOSA}

Sir :

Our previous papers ${ }^{1,2}$ indicated that polymyxin B (PLB) markedly induced the degradation of phospholipids in Pseudomonas aeruginosa AMS 6073 and that this phenomenon was caused by the in vivo activation of phospholipase which liberated fatty acids from the phospholipids. In the course of the work, we also detected diglycerides (DG) as products from exogeneously added phosphatidylethanolamine (PE) in the phospholipase assay system ${ }^{2}$. The present paper describes that phospholipase $\mathrm{C}$ (EC 3.1.4.3) is also activated in vivo by PLB.

The activity of the phospholipase $\mathrm{C}$ was assayed by the formation of 1,2-diacylglycerol from the substrate, PE. Enzyme fractions from control- and PLB- (or colistin-) treated cells were prepared as described in the previous paper ${ }^{2}$. The substrate, ${ }^{14} \mathrm{C}$-PE exclusively labeled in the fatty acid moieties, was also prepared as described earlier ${ }^{2}$ according to the procedure of DoI et al. ${ }^{3)}$ The standard reaction mixture contained $0.25 \mathrm{ml}$ of the enzyme solution, $0.25 \mathrm{ml}$ of $0.1 \mathrm{M}$ Tris- $\mathrm{HCl}$ buffer $(\mathrm{pH} 8.0)$ and $0.125 \mathrm{ml}$ of $800 \mu \mathrm{M}{ }^{14} \mathrm{C}$-PE in a total volume of $0.75 \mathrm{ml}$. The reaction mixture was incubated at $40^{\circ} \mathrm{C}$ with shaking for 60 minutes. After incubation, the reaction was terminated by adding $4.5 \mathrm{ml}$ chloroform - methanol (2:1) solution. The lipid materials in the reaction mixture were recovered by the modified extraction procedure of BLIGH \& DYER $^{4)}$. After the chloroform phase was evaporated to dryness, the resulting residue was dissolved in a small volume of chloroform - methanol (2:1) and spotted on a pre-coated thinlayer plate (Silica gel 60, E. Merck, Darmstadt
Germany: Code No. 5724). The identity of PE, DG and free fatty acid (F-FA) was established by comparing the $\mathrm{Rf}$ values of the spots with those of appropriate standards after development with two different solvent systems: chloroform methanol - water $(65: 25: 4)$ and petroleum ether - diethylether - acetic acid (80:30:1). Standard DG were prepared by hydrolysing purified PE with authentic phospholipase $\mathrm{C}$ from Bacillus cereus (Sigma Chemical Company, St. Louis, Mo., U.S.A.). After the autoradiography, areas corresponding to each spot were scraped off from the thin-layer plate. Their radioactivities were counted by a liquid scintillation spectrometer (Packard Tri-Carb 3385, Packard Instrument Company, Inc.) using a toluene scintillation fluid.

Table 1 indicates that the enzyme from PLB treated-cells degraded ${ }^{14} \mathrm{C}-\mathrm{PE}$ to F-FA and DG. Colistin, another polymyxin-group antibiotic, also induced the degradation of ${ }^{14} \mathrm{C}-\mathrm{PE}$ to the same extent as PLB. The degradation with untreated enzyme was of much lower order. It is evident that phospholipase $\mathrm{C}$ as well as F-FA liberating phospholipase(s) are activated by PLB and colistin in vivo.

In the previous paper, ${ }^{2)}$ we showed that an activation of F-FA liberating phospholipase(s) was observed with the cells that were incubated with PLB $(5 \mu \mathrm{g} / \mathrm{ml})$ only for 5 minutes. We performed a similar type of experiment with phospholipase C. The results were shown in Table 2. As reported previously, F-FA liberating phospholipase(s) was optimally activated in the cells that were incubated with PLB for only 5 minutes. By contrast, a longer time of incubation was required for the activation of phospholipase C. This result may be due to different locations of the enzymes. It has been already known that phospholipase $\mathrm{C}$ exists mainly as an extracellular enzyme in Pseudomonas aureo-

Table 1. Degradation of ${ }^{14} \mathrm{C}-\mathrm{PE}$ to $\mathrm{DG}$ and F-FA by enzyme fractions from control and PLB (or colistin) treated cells

\begin{tabular}{l|c|c|c|c}
\hline \multirow{2}{*}{ Treatment } & \multirow{2}{*}{$\begin{array}{c}\text { Enzyme } \\
\text { concentration } \\
\text { (mg protein/ml) }\end{array}$} & $\begin{array}{c}\text { Substrate } \\
\text { remaining }\end{array}$ & \multicolumn{2}{|c}{ D.P.M. (\% of total) } \\
\cline { 3 - 5 } & & PE & Reaction product \\
\hline None & 3.72 & $54,400(89.9)$ & $3,100(5.1)$ & $3,000(5.0)$ \\
PLB-treated $(5 \mu \mathrm{g} / \mathrm{ml})$ & 2.08 & $24,500(40.2)$ & $14,800(24.4)$ & $21,500(35.4)$ \\
Colistin-treated $(5 \mu \mathrm{g} / \mathrm{ml})$ & 2.56 & $27,500(41.0)$ & $16,100(24.0)$ & $23,400(35.0)$ \\
\hline
\end{tabular}


Table 2. Effect of incubation time with PLB on activation of ${ }^{14} \mathrm{C}-\mathrm{PE}$ degradation

\begin{tabular}{c|c|c|c|r}
\hline \multirow{2}{*}{$\begin{array}{c}\text { PLB treatment } \\
\text { of enzyme (min.) }\end{array}$} & $\begin{array}{c}\text { Enzyme } \\
\text { concentration } \\
\text { (mg protein/ml) }\end{array}$ & $\begin{array}{c}\text { Substrate } \\
\text { remaining }\end{array}$ & \multicolumn{2}{|c}{ Reaction product } \\
\cline { 3 - 5 } & PE (D.P.M.) & DG (D.P.M.) & F-FA (D.P.M.) \\
\hline 5 & 2.5 & 56,800 & 2,900 & 600 \\
10 & 2.3 & 49,600 & 4,700 & 6,500 \\
15 & 2.3 & 39,600 & 16,900 & 1,600 \\
30 & 2.7 & 38,600 & 16,100 & 2,000 \\
60 & 2.8 & 27,300 & 25,600 & 2,600 \\
\end{tabular}

* When the optical density of the culture reached 0.3 , PLB $(5 \mu \mathrm{g} / \mathrm{ml}$, final concentration) was added to the culture. Cells were harvested by centrifugation at times indicated and enzyme fractions were prepared from cells as described previously22.

Table 3. Effect of $\mathrm{CM}$ on the activation of ${ }^{14} \mathrm{C}$-PE degradation

\begin{tabular}{|c|c|c|c|c|}
\hline \multirow{3}{*}{$\begin{array}{l}\text { Treatment } \\
\text { of cells }\end{array}$} & \multirow{3}{*}{$\begin{array}{c}\text { Enzyme } \\
\text { concentration } \\
(\mathrm{mg} \text { protein } / \mathrm{ml})\end{array}$} & \multicolumn{3}{|c|}{$\%$ of total radioactivity } \\
\hline & & \multirow{2}{*}{$\frac{\text { Substrate remaining }}{\mathrm{PE}}$} & \multicolumn{2}{|c|}{ Reaction products } \\
\hline & & & DG & F-FA \\
\hline None & 2.0 & 92.8 & 5.9 & 1.3 \\
\hline PLB & 2.0 & 66.2 & 30.5 & 3.3 \\
\hline $\mathrm{CM}$ & 2.0 & 96.2 & 2.7 & 1.1 \\
\hline $\mathrm{CM}+\mathrm{PLB}$ & 2.0 & 81.1 & 16.4 & 2.5 \\
\hline
\end{tabular}

At the optical density of 0.3 , the culture was divided into two fractions, one of which was incubated with $\mathrm{CM}(200 \mu \mathrm{g} / \mathrm{ml})$ for 30 minutes. They both incubated fractions were again divided into two protions. PLB $(5 \mu \mathrm{g} / \mathrm{ml})$ was added to the one portion of each fraction and all cultures were further incubated for 60 minutes. After incubation, the cells were harvested by centrifugation. Enzymes were prepared as described earlier ${ }^{2}$.

faciens $^{5,6)}$ and phospholipase A in $P$. aeruginosa ${ }^{7)}$ exists as an outer membrane-bound enzyme.

There are some data that suggest phospholipase $\mathrm{A}$ in Bacillus subtilis, ${ }^{8}$ Escherichia coli ${ }^{9}$, and bacteriophage $\mathrm{T}^{10}{ }^{10}$ exists in a "latent" form similar to bacterial lytic enzymes. Consequently, we examined whether or not the activation of phospholipase C by PLB occurred in the presence of $200 \mu \mathrm{g} / \mathrm{ml}$ of chloramphenicol (CM: Sankyo Co., Ltd., Tokyo). This concentration of CM completely inhibited the protein synthesis in this organism. As shown in Table 3, activation of phospholipase $\mathrm{C}$ induced by PLB occurred even in the presence of $\mathrm{CM}$. A similar result was obtained with the F-FA liberating phospholipase(s). The induced activities of both enzymes were, however, less than those obtained in the absence of CM. These results indicate that both phospholipases exist primarily in latent forms.

TOMONOBU Kusano

KAZUO IZAKI

HAJIME TAKAHASHI
Department of Agricultural Chemistry Faculty of Agriculture

Tohoku University, Sendai, Japan

(Received July 28, 1977)

\section{References}

1) Kusano, T.; K. Izaki \& H. TaKahashi: Degradation of phospholipid in Pseudomonas aeruginosa induced by polymyxin B. J. Antibiotics 28: 689 695, 1975

2) Kusano, T.; K. IzaKi \& H. TAKaHashi: In vivo activation by polymyxin $\mathrm{B}$ of phospholipase from Pseudomonas aeruginosa and Escherichia coli. J. Antibiotics 29: 674 675, 1976

3) Dor, O. \& S. Noנrma: Phospholipase C from Pseudomonas fluorescens. Biochim. Biophys. Acta 248: $234 \sim 244,1971$

4) Bligh, E. G. \& W. J. Dyer: A rapid method of total lipid extraction and purification. Canad. J. Biochem. Physiol. 37: $911 \sim 917,1959$

5) Sonoki, S. \& H. Ikezawa: Studies on phospholipase C from Pseudomonas aureofaciens. I. Purification and some properties of phospholipase C. Biochim.Biophys. Acta 403: 412 424, 


\section{5}

6) Sonoki, S. \& H. Ikezawa: Studies on phospholipase C from Pseudomonas aureofaciens. II. Further studies on the properties of the enzyme. J. Biochem. (Tokyo) 80: 361 366, 1976

7) Воотн, B. R. \& N. A. C. Curtis: Separation of the cytoplasmic and outer membrane of Pseudomonas aeruginosa PAO 1. Biochem. Biophys. Res. Commun. 74: 1168 1176, 1977

8) Kent, C. \& W. Lennarz: An osmotically fragile mutant of Bacillus subtilis with an active membrane-associated phospholipase A1. Proc.
Natl. Acad. Sic., U.S.A. 69: 2793 2797, 1972

9) Nishijima, M.; S. Nakaike, Y. Tamori \& S. NoJima: Detergent-resistant phospholipase A of Escherichia coli K-12. Purification and properties. Eur. J. Biochem. 73: 115 124, 1977

10) Nelson, E. T. \& C. S. Buller: Phospholipase activity in bacteriophage-infected Escherichia coli. I. Demonstration of a T4 bacteriophageassociated phospholipase. J. Virol. 14: 479 484, 1974 